NASA/TM-2002-211126

\title{
Integrating Oil Debris and Vibration Gear Damage Detection Technologies Using Fuzzy Logic
}

Paula J. Dempsey

Glenn Research Center, Cleveland, Ohio

Abdollah A. Afjeh

University of Toledo, Toledo, Ohio 
The NASA STI Program Office ... in Profile

Since its founding, NASA has been dedicated to the advancement of aeronautics and space science. The NASA Scientific and Technical Information (STI) Program Office plays a key part in helping NASA maintain this important role.

The NASA STI Program Office is operated by Langley Research Center, the Lead Center for NASA's scientific and technical information. The NASA STI Program Office provides access to the NASA STI Database, the largest collection of aeronautical and space science STI in the world. The Program Office is also NASA's institutional mechanism for disseminating the results of its research and development activities. These results are published by NASA in the NASA STI Report Series, which includes the following report types:

- TECHNICAL PUBLICATION. Reports of completed research or a major significant phase of research that present the results of NASA programs and include extensive data or theoretical analysis. Includes compilations of significant scientific and technical data and information deemed to be of continuing reference value. NASA's counterpart of peerreviewed formal professional papers but has less stringent limitations on manuscript length and extent of graphic presentations.

- TECHNICAL MEMORANDUM. Scientific and technical findings that are preliminary or of specialized interest, e.g., quick release reports, working papers, and bibliographies that contain minimal annotation. Does not contain extensive analysis.

- CONTRACTOR REPORT. Scientific and technical findings by NASA-sponsored contractors and grantees.
- CONFERENCE PUBLICATION. Collected papers from scientific and technical conferences, symposia, seminars, or other meetings sponsored or cosponsored by NASA.

- SPECIAL PUBLICATION. Scientific, technical, or historical information from NASA programs, projects, and missions, often concerned with subjects having substantial public interest.

- TECHNICAL TRANSLATION. Englishlanguage translations of foreign scientific and technical material pertinent to NASA's mission.

Specialized services that complement the STI Program Office's diverse offerings include creating custom thesauri, building customized data bases, organizing and publishing research results ... even providing videos.

For more information about the NASA STI Program Office, see the following:

- Access the NASA STI Program Home Page at http://www.sti.nasa.gov

- E-mail your question via the Internet to help@sti.nasa.gov

- Fax your question to the NASA Access Help Desk at 301-621-0134

- Telephone the NASA Access Help Desk at 301-621-0390

- Write to: NASA Access Help Desk NASA Center for AeroSpace Information 7121 Standard Drive Hanover, MD 21076 
NASA/TM-2002-211126

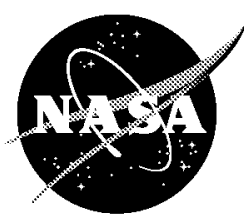

\section{Integrating Oil Debris and Vibration Gear Damage Detection Technologies Using Fuzzy Logic}

Paula J. Dempsey

Glenn Research Center, Cleveland, Ohio

Abdollah A. Afjeh

University of Toledo, Toledo, Ohio

Prepared for the

International 58th Annual Forum and Technology Display sponsored by the American Helicopter Society

Montreal, Quebec, Canada, June 11-13, 2002

National Aeronautics and

Space Administration

Glenn Research Center

July 2002 
Available from

NASA Center for Aerospace Information 7121 Standard Drive

Hanover, MD 21076
National Technical Information Service 5285 Port Royal Road Springfield, VA 22100

Available electronically at http://gltrs.grc.nasa.gov/GLTRS 


\title{
Integrating Oil Debris and Vibration Gear Damage Detection Technologies Using Fuzzy Logic
}

\author{
Paula J. Dempsey \\ National Aeronautics and Space Administration \\ Glenn Research Center \\ Cleveland, Ohio 44135 \\ Abdollah A. Afjeh \\ The University of Toledo \\ Toledo, Ohio 43606
}

\begin{abstract}
A diagnostic tool for detecting damage to spur gears was developed. Two different measurement technologies, wear debris analysis and vibration, were integrated into a health monitoring system for detecting surface fatigue pitting damage on gears. This integrated system showed improved detection and decision-making capabilities as compared to using individual measurement technologies. This diagnostic tool was developed and evaluated experimentally by collecting vibration and oil debris data from fatigue tests performed in the NASA Glenn Spur Gear Fatigue Test Rig. Experimental data were collected during experiments performed in this test rig with and without pitting. Results show combining the two measurement technologies improves the detection of pitting damage on spur gears.
\end{abstract}

\section{Introduction}

One technology area recommended for helicopter accident reduction is the design of helicopter Health Usage Monitoring Systems (HUMS) capable of predicting imminent equipment failure for on-condition maintenance and a more advanced system capable of warning pilots of impending equipment failure. Today's helicopter health monitoring systems (HUMS) are not at this level. Data collected by HUMS is often processed after the flight and plagued with high false alarm rates and undetected faults. The current fault detection rate of commercially available HUMS through vibration analysis is 70 percent [1]. False warning rates average 1 per hundred flight hours [2]. Often these systems are complex and require extensive interpretation by trained diagnosticians [3].

Transmission diagnostics are an important part of a helicopter HUMS because helicopters depend on the power train for propulsion, lift, and flight maneuvering. In order to predict transmission failures, the diagnostic tools used in the health monitoring system must provide real-time performance monitoring of aircraft operating parameters and must demonstrate a high level of reliability to minimize false alarms.
Various techniques exist for diagnosing damage in helicopter transmissions. The method most widely used involves vibration. Algorithms are developed, using vibration data collected from gearbox accelerometers, to detect when gear damage has occurred. Oil debris is also used to identify abnormal wear related conditions at an early stage. Oil debris monitoring for gearboxes consists mainly of off-line oil analysis, or plug type chip detectors. Although not commonly used for gear damage detection, many engines have on-line oil debris sensors for detecting the failure of rolling element bearings. These on-line, inductance type sensors count the number of particles, their approximate size, then calculate an accumulated mass.

Integrating the sensors into one system can potentially improve the detection capabilities and the probability that damage is detected. Recent investigations have shown the benefits of using an oil debris monitor with vibration data to improve current HUMS, but have not fully demonstrated a system with improved detection and decisionmaking capability when integrating the two measurement systems [4], [5].

The objective of the work reported herein is to improve the detection capability of vibration and oil based damage detection features by applying fuzzy logic analysis techniques to gear failure data collected from the NASA Glenn Spur Gear Fatigue Rig. A simple model was defined by the fuzzy rules and the membership functions for the experiments when pitting damage occurred. The ability to define valid ranges and limits for each membership function was found to be critical to the success of the model at predicting damage.

Vibration data were collected from accelerometers and used in previously validated gear vibration diagnostic algorithms. Oil debris data were collected using a commercially available in-line oil debris sensor. Oil debris and vibration data will be integrated using fuzzy logic analysis techniques. The goal of this research is to provide the end user with a simple tool to determine reliably the health of this geared system. 


\section{Experimental Investigation}

Experimental data were recorded from 24 experiments performed in the Spur Gear Fatigue Test Rig at NASA Glenn Research Center. A sketch of the test rig is shown in Figure 1. The facility operates on the torque regenerative principle. Torque is applied by a hydraulic loading mechanism that twists one slave gear relative to its shaft. The power required to drive the system is only enough to overcome friction losses in the system [6]. The test gears are standard spur gears having 28 teeth, 3.50 inch $(8.89 \mathrm{~cm})$ pitch diameter, and 0.25 inch $(0.635 \mathrm{~cm})$ face width. The test gears are run offset to provide a narrow effective face width to maximize gear contact stress while maintaining an acceptable bending stress. Offset testing also allows four tests on one pair of gears. Two filters are located downstream of the oil debris monitor to capture the debris after it is measured by the sensor.

Fatigue tests were run in a manner that allows damage to be correlated to the oil debris sensor data. For these tests, run speed was 10,000 RPM and applied torque was 53 or $71 \mathrm{ft}$-lbs. (72 or 96 $\mathrm{N} \cdot \mathrm{m})$. Prior to collecting test data, the gears were run for 1 hour at a torque of $10 \mathrm{ft}-\mathrm{lbs}$. $(14 \mathrm{~N} \cdot \mathrm{m})$. Test gears were inspected periodically for fatigue damage throughout the duration of the test. When damage was found, the damage was documented and correlated to the test data based on a reading number. Reading number refers to the once per minute data collection rate. Reading number is equivalent to minutes and can also be interpreted as mesh cycles equal to reading number times $10^{4}$. In order to document tooth damage, reference marks are made on the driver and driven gears during installation to identify tooth 1 . The mating teeth numbers on the driver and driven gears are then numbered from this reference. Figure 2 identifies the driver and driven gear with the gearbox cover removed.

The principal focus of this research is the detection of pitting damage on spur gears. Pitting is a fatigue failure caused by exceeding the surface fatigue limit of the gear material. Pitting occurs when small pieces of material break off from the gear surface, producing pits on the contacting surfaces [7]. Gears are run until pitting occurs on one or more several teeth. Two levels of pitting were monitored, initial (pits less than $0.0397 \mathrm{~cm}$ diameter and cover less than 25 percent of tooth contact area) and destructive pitting (pits greater than $0.0397 \mathrm{~cm}$ diameter and cover greater than 25 percent of tooth contact area). If not detected in time, destructive pitting can lead to a catastrophic transmission failure if the gear teeth crack.

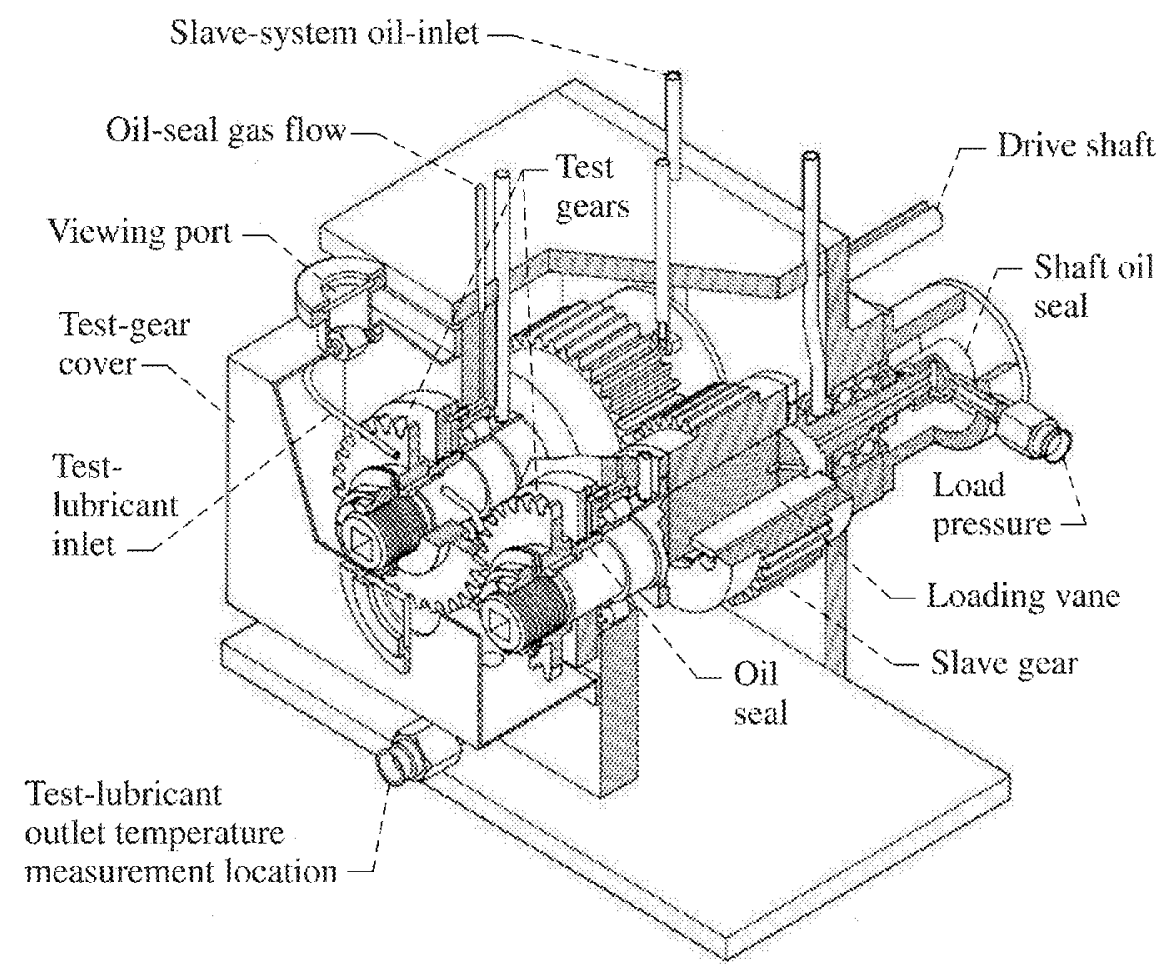

Figure 1: Spur Gear Fatigue Rig Gearbox 


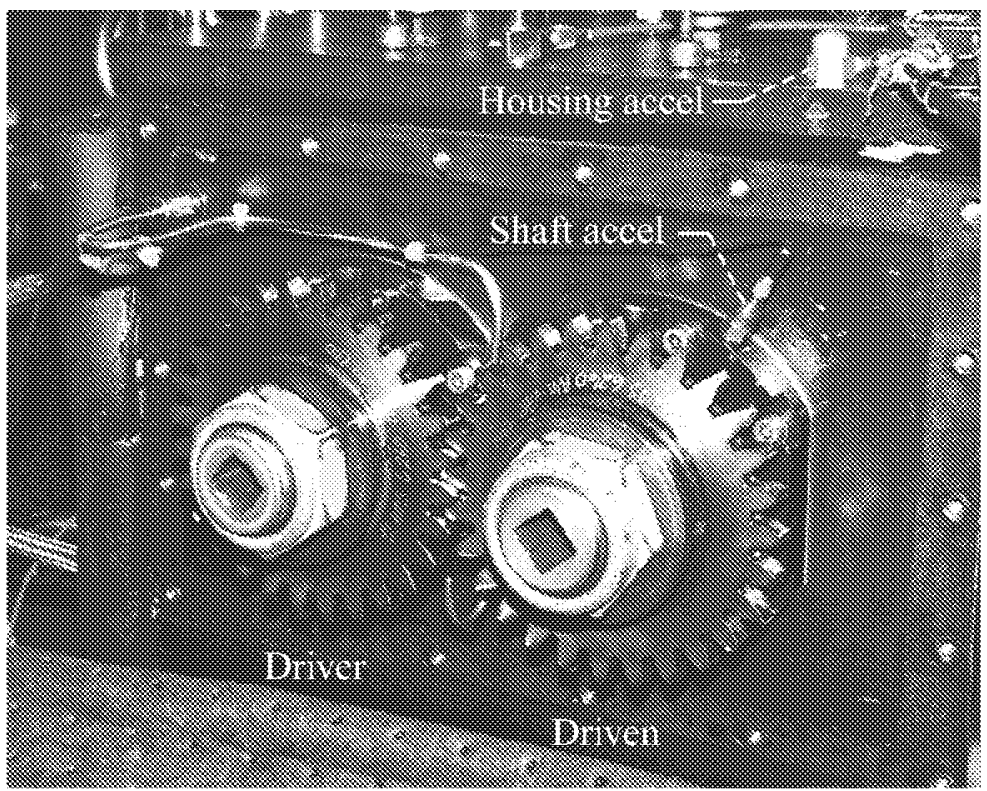

Figure 2: Spur Gear Fatigue Rig Gearbox With Cover Removed

Data were collected using vibration, oil debris, speed and pressure sensors installed on the test rig. Vibration was measured on the gear housing and at a support bearing location using miniature, lightweight, piezoelectric accelerometers. Location of both sensors is shown in Figure 2. These locations were chosen based on an analysis of optimum accelerometer locations for this test rig [8]. Oil debris data were collected using a commercially available oil debris sensor that measures the change in a magnetic field caused by passage of a metal particle where the amplitude of the sensor output signal is proportional to the particle mass. The sensor measures the number of particles, their approximate size (125 to 1000 microns) and calculates an accumulated mass [9]. Shaft speed was measured by an optical sensor once per revolution of the shaft. Load pressure was measured using a capacitance pressure transducer.

Oil debris sensor, speed, pressure, and raw vibration data were collected and processed in real-time using the data acquisition program ALBERT, Ames-Lewis Basic Experimentation in Real Time, co-developed by NASA Glenn and Ames. Oil debris and pressure data were recorded once per minute. Vibration and speed data were sampled at $200 \mathrm{KHz}$ for one-second duration every minute. Vibration algorithms FM4 and NA4 Reset were calculated from this data and recorded every minute. Time-synchronous averaging was performed from the raw vibration data for 113 revolutions of the test gear. The signal timesynchronous average is obtained by taking the average of the signal in the time domain with each record starting at the same point in the cycle as determined by the once per gear revolution tachometer signal [10]. The time-synchronous average data were then used to calculate the two vibration diagnostic parameters FM4 and NA4 Reset. FM4 and NA4 are dimensionless parameters with nominal values of approximately 3. When gear damage occurs, the value increases for both FM4 and NA4 [11].

FM4 was developed to detect changes in the vibration pattern resulting from fatigue damage on a limited number of teeth [12]. The theory behind FM4 is that for a gear in good condition, the difference signal would be noise with a Gaussian amplitude distribution. The standard deviation should be relatively constant, and normalized kurtosis indicates a value of three. When a tooth develops a major defect, a peak or series of peaks appear in the difference signal, causing the kurtosis value to increase [10]. One problem with the FM4 parameter is that it decreases in sensitivity as the number of peaks of similar magnitude increase beyond two. For this reason, NA4 was developed for failures that involve more than two teeth.

NA4 was developed to detect the onset of fatigue damage and to continue to react to the damage as it spreads [13]. However, it does not perform well under fluctuating load conditions. Preliminary tests found NA4 sensitive to minor changes in load. NA4 Reset was developed from NA4 for applications with load fluctuations [14]. 
The oil debris monitor records counts of particles in bins set at a particle size range. The particle size is measured in microns. For these experiments, 16 bins were defined. The range of the bin sizes in microns is shown in Table 1. Based on the bin configuration, the average particle size for each bin is used to calculate the cumulative mass for the experiment. Previous research verified accumulated mass is a good predictor of pitting damage and identified threshold limits that discriminate between stages of pitting on spur gears [15].

During each experiment, measurements from two accelerometers and an oil debris sensor were monitored and recorded for the occurrence of pitting damage. The data measured from the vibration and oil debris sensors during experiments with and without damage were used to identify membership functions to build a simple fuzzy logic model. Using this fuzzy logic model, and the vibration and oil debris data, threshold limits were defined that discriminate between different levels of pitting wear.

\section{Discussion of Results}

The analysis discussed in this section is based on data collected during 24 experiments, 15 of which had pitting damage occur. Video inspection images are available for 13 of the experiments with pitting damage, 2 were performed prior to installation of the video inspection system.

Table 2 is a summary of the experiments performed and a description of the damage. The second column lists the reading number the pitting was first observed via video or manual inspection. Video inspection was used during Experiments 1 to 6 and 18 to 24. Manual inspection was used for experiments 7 to 17 . The "oil debris" column is the amount of debris measured at this reading. The last reading collected for this experiment is listed in the fifth column. All gears were visually inspected at test completion and the damage description and amount of debris at this time are listed in the last 2 columns. The damage description gives the damage observed on the driver (Dr) and driven (Dn) gears. Damage is defined as initial pitting (ip), and destructive pitting (de) to the total number of teeth for each gear. For example, Dr: de 3t, ip allt, is driver gear had destructive pitting on 3 teeth and initial pitting on all of the teeth. A detailed description of the damage to each tooth was correlated with the video images for each experiment.

A representative sample of a detailed damage description for each tooth, and the images obtained from the video inspection system is shown in Table 3 and Figure 3 . The damage progression video images of tooth 11 on the driver and driven gear for Experiment 2 are shown in this figure. The damage is only shown on less than half of the tooth because the test gears are run offset to provide a narrow effective face width to maximize gear contact stress.

Fuzzy logic techniques were applied to the oil debris and vibration data in order to build a simple model that discriminates between stages of pitting wear. Fuzzy logic applies fuzzy set theory to data, where fuzzy set theory is a theory of classes with unsharp boundaries and the data belongs in a set based on its degree of membership [16]. The degree of membership can be any value between 0 and 1 . The advantage of applying fuzzy logic to condition based maintenance is that it is flexible, making allowances for unanticipated behavior.

Table 1: Oil Debris Particle Size Ranges

\begin{tabular}{|c|c|c||c|c|c|}
\hline Bin & $\begin{array}{c}\text { Bin range, } \\
\mu \mathrm{m}\end{array}$ & Average & Bin & $\begin{array}{c}\text { Bin range, } \\
\mu \mathrm{m}\end{array}$ & Average \\
\hline 1 & $125-175$ & 150 & 9 & $525-575$ & 550 \\
\hline 2 & $175-225$ & 200 & 10 & $575-625$ & 600 \\
\hline 3 & $225-275$ & 250 & 11 & $625-675$ & 650 \\
\hline 4 & $275-325$ & 300 & 12 & $675-725$ & 700 \\
\hline 5 & $325-375$ & 350 & 13 & $725-775$ & 750 \\
\hline 6 & $375-425$ & 400 & 14 & $775-825$ & 800 \\
\hline 7 & $425-475$ & 450 & 15 & $825-900$ & 862.5 \\
\hline 8 & $475-525$ & 500 & 16 & $900-1016$ & 958 \\
\hline
\end{tabular}


Table 2: Summary of Experiments

\begin{tabular}{|c|c|c|c|c|c|c|}
\hline $\begin{array}{c}\text { Experiment } \\
\text { Number }\end{array}$ & $\begin{array}{l}\text { Rdg Pilting } \\
\text { First Observed }\end{array}$ & $\begin{array}{l}\text { Damage } \\
\text { Description }\end{array}$ & $\begin{array}{l}\text { Oil Debris } \\
\text { (mg) }\end{array}$ & $\begin{array}{l}\text { Ridg at Test } \\
\text { Completion }\end{array}$ & $\begin{array}{l}\text { Damage } \\
\text { Description }\end{array}$ & $\begin{array}{l}\text { Oil Debris } \\
\text { (mg) }\end{array}$ \\
\hline 1 & 14369 & $\begin{array}{l}\text { Dr: de } 1 \mathrm{t} \\
\text { Dn: de } 1 \mathrm{t}\end{array}$ & 15.475 & 15136 & $\begin{array}{l}\text { Dr: de 3t, ip allt } \\
\text { Dn: de 3t }\end{array}$ & 36.108 \\
\hline 2 & 2199 & $\begin{array}{l}\text { Dr: } \\
\text { Dn: de 1t }\end{array}$ & 8.934 & 2444 & $\begin{array}{l}\text { Dr: de 2t, ip allt } \\
\text { Dn de 3t, ip 3t }\end{array}$ & 26.268 \\
\hline 3 & 2669 & $\begin{array}{l}\text { Dr: de } 2 t \\
\text { Dn: de } 2 t\end{array}$ & 8.690 & 3029 & $\begin{array}{l}\text { Dr: de 3t, ip allt } \\
\text { Dn: de 3t, ip3t }\end{array}$ & 14.148 \\
\hline 4 & 2065 & $\begin{array}{l}\text { Dr: de 3t } \\
\text { Dn: }\end{array}$ & 12.132 & 4863 & $\begin{array}{l}\text { Dr: de } 7 \mathrm{t} \text {, ip allt } \\
\text { Dn de } 3 \mathrm{t} \text {, ip allt }\end{array}$ & 26.227 \\
\hline 5 & 2566 & $\begin{array}{l}\text { Dr: ip 2t } \\
\text { Dn: }\end{array}$ & 7.413 & 4425 & $\begin{array}{l}\text { Dr: de } 11 \mathrm{t} \text {, ip allt } \\
\text { Dn de } 10 \mathrm{t} \text {, ip allt }\end{array}$ & 10.811 \\
\hline 6 & 12061 & $\begin{array}{l}\text { Dr: } \\
\text { Dn: de } 1 \mathrm{t}\end{array}$ & 14.365 & 12368 & $\begin{array}{l}\text { Dr: de } 1 \mathrm{t} \text {, ip allt } \\
\text { Dn de } 2 t \text {, ip allt }\end{array}$ & 22.851 \\
\hline 7 & & & & 13716 & $\begin{array}{l}\text { Dr: ip 1t } \\
\text { Dn ip 1t }\end{array}$ & 3.381 \\
\hline 8 & 5181 & $\begin{array}{l}\text { Dr: ip 2t } \\
\text { Dn: ip 3t }\end{array}$ & 6.012 & 5314 & $\begin{array}{l}\text { Dr: de 6t, ip8t } \\
\text { Dn de6t, ip7t }\end{array}$ & 19.101 \\
\hline 9 & & & & 29866 & No damage & 2.359 \\
\hline 10 & & & & 20452 & No damage & 5.453 \\
\hline 11 & & & & 204 & No damage & 0.418 \\
\hline 12 & & & & 15654 & No damage & 2.276 \\
\hline 13 & & & & 25259 & No damage & 3.159 \\
\hline 14 & & & & 5322 & No damage & 0 \\
\hline 15 & & & & 21016 & No damage & 0.125 \\
\hline 16 & & & & 380 & No damage & 0.099 \\
\hline 17 & & & & 21066 & No damage & 0.064 \\
\hline 18 & & & & 888 & $\begin{array}{l}\text { Dr: de 6t, ip allt } \\
\text { Dn de 4t, ip allt }\end{array}$ & 22.541 \\
\hline 19 & & & & 199 & $\begin{array}{l}\text { Dr: de 3t, ip allt } \\
\text { Dn de } 1 \mathrm{t} \text {, ip allt }\end{array}$ & 11.230 \\
\hline 20 & & & & 1593 & $\begin{array}{l}\text { Dr: de 1t, ip allt } \\
\text { Dn ip allt }\end{array}$ & 5.346 \\
\hline 21 & 317 & $\begin{array}{l}\text { Dr: de } 1 t \\
\text { Dn: de } 1 \mathrm{t}\end{array}$ & 4.04 & 514 & $\begin{array}{l}\text { Dr: de } 2 t \text {, ip allt } \\
\text { Dn: de } 2 t \text {, ip allt }\end{array}$ & 17.912 \\
\hline 22 & & & & 838 & $\begin{array}{l}\text { Dr: ip 5t } \\
\text { Dn: de 3t, ip allt }\end{array}$ & 7.224 \\
\hline 23 & & & & 10688 & $\begin{array}{l}\text { Dr: de } 2 t \text {, ip allt } \\
\text { Dn: de } 1 \mathrm{t} \text {, ip allt }\end{array}$ & 6.399 \\
\hline 24 & 7170 & $\begin{array}{l}\text { Dr: de 1t } \\
\text { Dn: }\end{array}$ & 6.186 & 7224 & $\begin{array}{l}\text { Dr: de 1t, ip allt } \\
\text { Dn: ip allt }\end{array}$ & 9.681 \\
\hline
\end{tabular}

Note: ip=initial pitting; de=destructive pitting; $\mathrm{Dr}=$ driver gear; $\mathrm{Dn}=$ driven gear; $\mathrm{Xt}=$ number of teeth with damage 
Table 3: Damage Description for Experiment 2

\begin{tabular}{|c|c|c|c|}
\hline $\begin{array}{c}\text { Reading } \\
\text { Number } \\
\text { Run Time (min) }\end{array}$ & Damage Description & $\begin{array}{l}\text { Teeth Damaged } \\
\text { on Driver Gear }\end{array}$ & $\begin{array}{l}\text { Teeth Damaged } \\
\text { on Driven Gear }\end{array}$ \\
\hline 1573 & Run-in Wear & All & All \\
\hline 2199 & $\begin{array}{c}\text { Wear } \\
\text { Destructive Pitting }\end{array}$ & All & $\begin{array}{r}\text { All } \\
11\end{array}$ \\
\hline 2296 & $\begin{array}{c}\text { Wear } \\
\text { Destructive Pitting }\end{array}$ & All & $\begin{array}{c}\text { All } \\
10,11\end{array}$ \\
\hline 2444 & $\begin{array}{c}\text { Wear } \\
\text { Initial Pitting } \\
\text { Destructive Pitting }\end{array}$ & $\begin{array}{c}\text { All } \\
\text { All } \\
10,11\end{array}$ & $\begin{array}{c}\text { All } \\
10,11,14 \\
10,11,14\end{array}$ \\
\hline
\end{tabular}

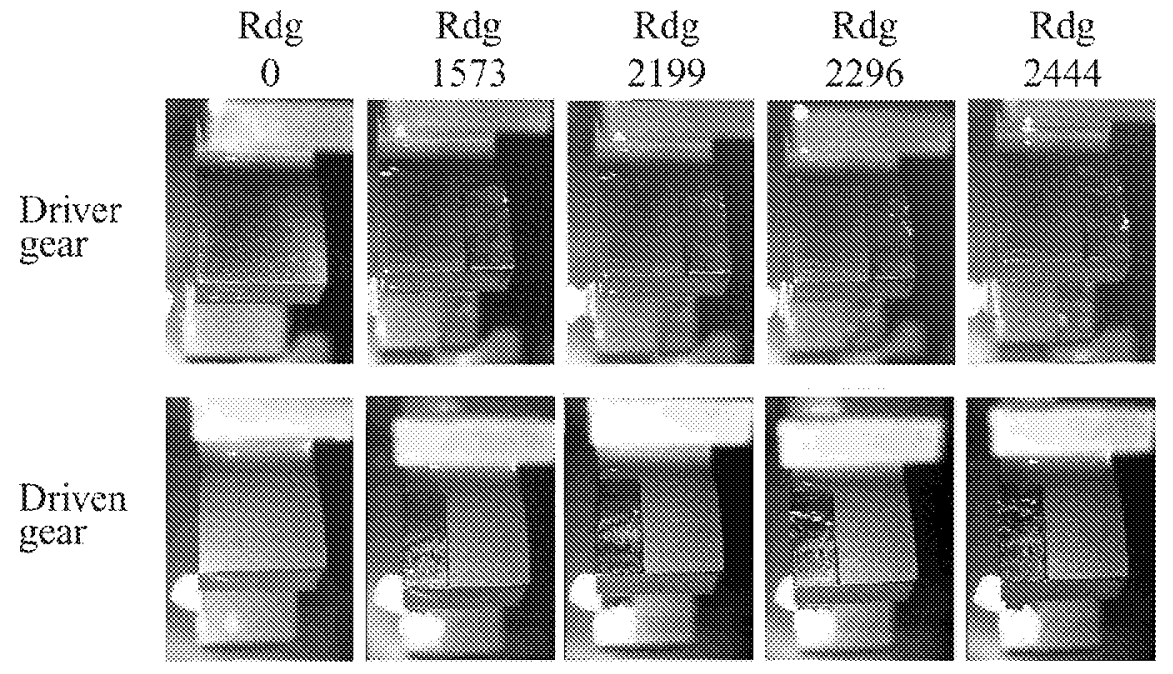

Figure 3: Damage Progression of Driver/Driven Tooth 11 for Experiment 2

Mamdani's fuzzy inference system is the most common seen fuzzy methodology and used for this application [17]. It is based on the paper on fuzzy algorithms for decision processes [18]. In the Mamdani type inference systems the output membership functions are fuzzy sets. The process is detailed below [19]

1. fuzzify inputs or fuzzification: converts each piece of input data to degrees of membership by a lookup in one of several membership functions.

2. apply fuzzy operator: $A N D=$ minimum; $O R=$ maximum

3. apply implication methods: apply weight to rule; output fuzzy set is truncated and scaled.

4. aggregate all outputs: aggregation is the process by which fuzzy sets represent the outputs of each rule and are combined into a single fuzzy set.

5. defuzzify: output is a single number. Middle of maximum (the average of the maximum value of the output set)
Defining the fuzzy logic model requires inputs (damage detection features), outputs (state of gear), and rules. Commercially available software was used to build the model because it was a convenient tool for mapping an input space to an output space and creating and editing fuzzy inference systems [20]. Input space for this model was defined as damage low (DL), damage medium (DM), and damage high $(\mathrm{DH})$, indicated by the following features: oil debris mass (DL, DM, DH), NA4 Reset (DL, DH), and FM4 (DL, DH). The output space for this model was defined as the state of the gear. The 3 states of the gear to predict with this model were identified as: O.K. (no gear damage); Inspect (initial/destructive pitting); Shutdown due to damage (severe destructive pitting). The Mean of the maximum (MOM) was chosen as the defuzzification method. MOM was chosen because it gave the most plausible results for this application. The MOM method finds the output with the maximum membership and takes the $\mathrm{x}$-axis average of all points with this maximum 
membership value. If there is more than one point that has maximum degree of membership, the mean of the points are taken. The membership functions were based on the data collected during experiments 1 to 17 .

For the oil debris sensor, membership values were based on the accumulated mass and the amount of damage observed the teeth via video or visual inspection. Membership values are defined for 3 levels of damage: damage low (DL), damage medium (DM), and damage high $(\mathrm{DH})$ and are shown in Figure 4. The process used to define membership functions for the oil debris sensor are published in an earlier paper and indicate accumulated mass is a good predictor of pitting damage on spur gears and fuzzy logic is a good technique for setting threshold limits that discriminates between states of pitting wear [15]

FM4 is the vibration feature developed to detect changes in the vibration pattern due to damage on a limited number of teeth. When gear damage occurs, the FM4 value increases, and then decreases as it progresses to a number of teeth. FM4 was calculated for the accelerometers located on the bearing support and the housing. The maximum value of FM4 measured by the two accelerometers was used for further analysis. FM4 membership values were defined by looking at the maximum FM4 value within each inspection interval. Membership values are defined for 2 levels of damage: damage low (DL) and damage high $(\mathrm{DH})$. The membership function for FM4 is shown in Figure 5. Due to FM4's insensitivity to damage progression, logic is programmed into the model to freeze the FM4 when it exceeds 7.68 .

NA4 Reset, like FM4, is less sensitive to damage as it progresses to a number of teeth and increases in severity. Although, the magnitude of NA4 Reset is significantly larger than FM4 when pitting damage begins to occur, like FM4, NA4 reset decreases as damage progresses to a number of teeth. NA4 was calculated for the accelerometers located on the bearing support and the housing. The maximum value of NA4 measured by the two accelerometers was used for further analysis. NA4 membership values were defined by looking at the maximum NA4 value within each inspection interval. Membership values are defined for 2 levels of damage: damage low $(\mathrm{DL})$ and damage high $(\mathrm{DH})$. The membership function for NA4 is shown in Figure 6. Due to NA4's insensitivity to damage progression, logic is programmed into the model to freeze the NA4 when it exceeds 12.60 .

The degree of membership for the output of the fuzzy model is shown in Figure 7. The output is the status or state of the gear: O.K. (no gear damage); Inspect (initial pitting); Damage (destructive pitting). The rules defined for the model are listed in Table 4. Using the membership values and rules for the vibration and oil debris features, and the Mean of the Maximum (MOM) fuzzy logic defuzzification method, a simple fuzzy logic model was developed. The input/output data to the fuzzy model for each experiment will be discussed in the following paragraphs.

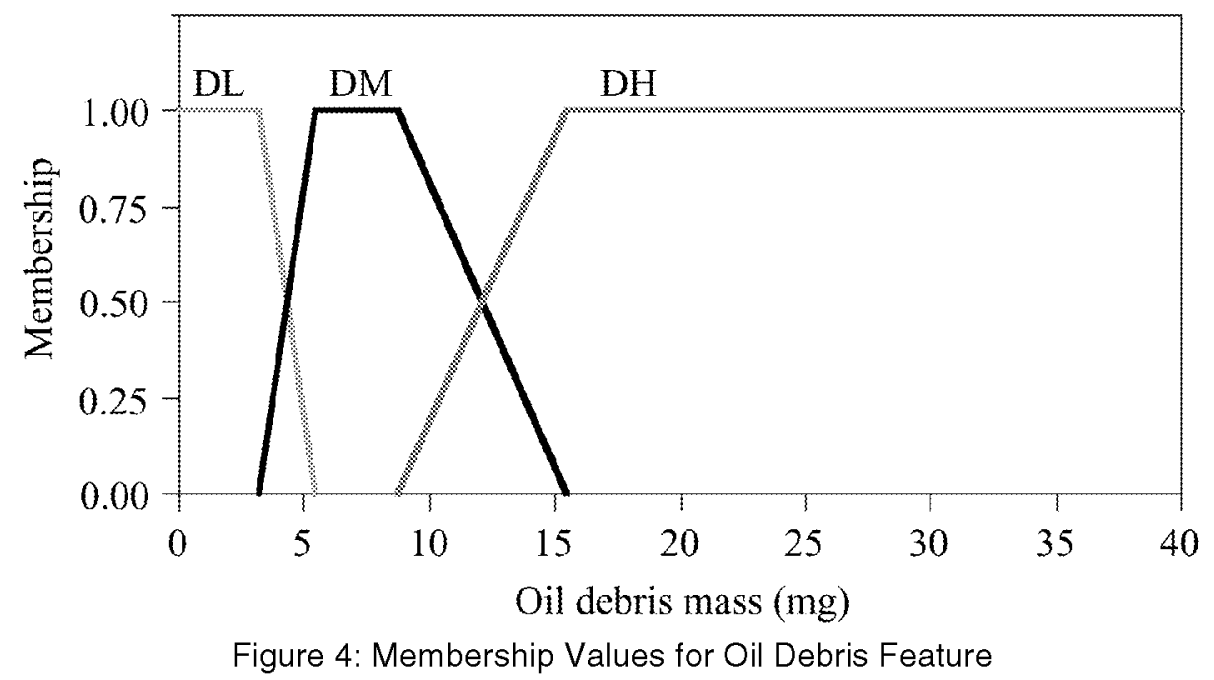

NASA/TM-2002-211126 


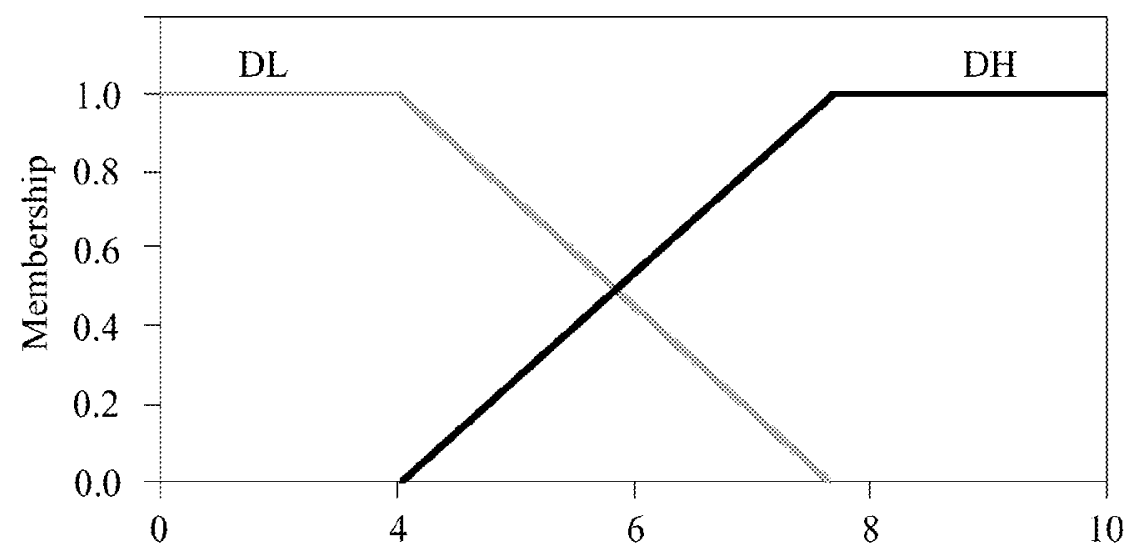

FM4

Figure 5: Membership Values for FM4 Feature

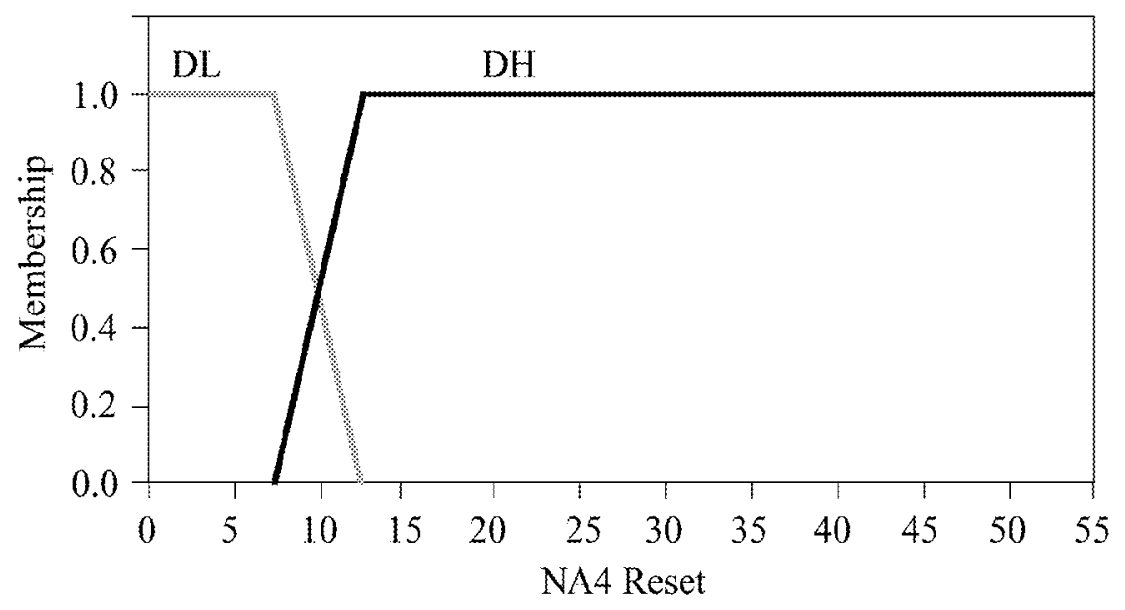

Figure 6: Membership Values for NA4 Feature

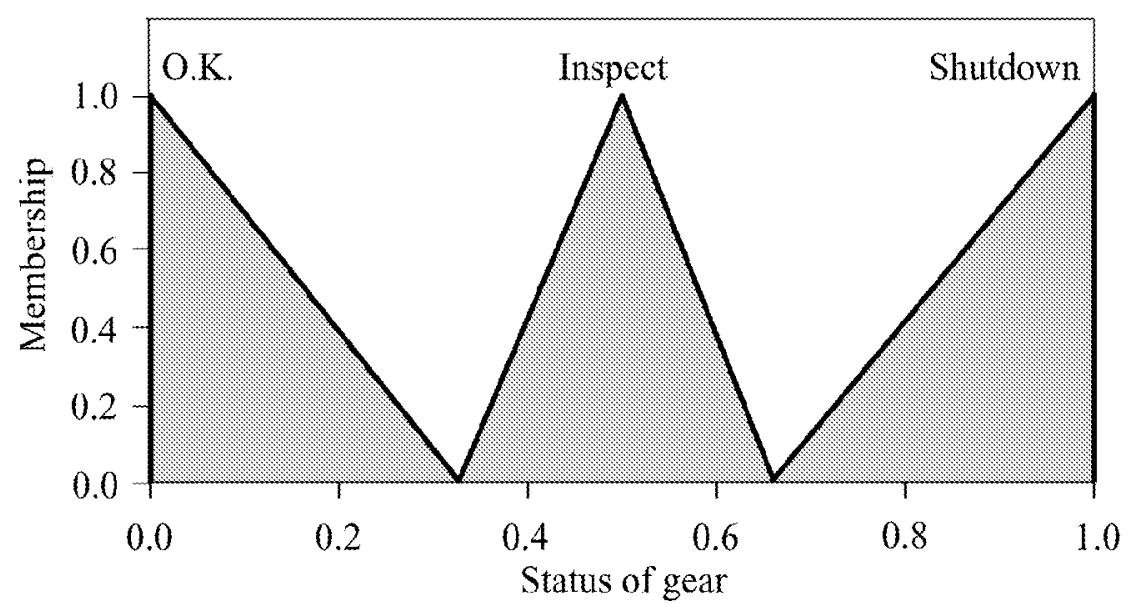

Figure 7: Output of Fuzzy Logic Model 
Table 4: Rules for Fuzzy Logic Model

\begin{tabular}{|c|c|}
\hline 1. & ut is $\mathrm{O} . \mathrm{K}$. ) \\
\hline 2. & If (FM4 is $\mathrm{DH})$ and (NA4 is $\mathrm{DH}$ ) and (debris is $\mathrm{DH}$ ) then (output is SHUTDOWN) \\
\hline 3. & If (FM4 is DL) and (NA4 is DL) and (debris is DM) then (output is INSPECT) \\
\hline 4. & If (FM4 is DL) and (NA4 is DH) and (debris is DL) then (output is O.K.) \\
\hline 5. & If (FM4 is DL) and (NA4 is DL) and (debris is DH) then (output is INSPECT) \\
\hline 6. & If (FM4 is DH) and (NA4 is DL) and (debris is DL) then (output is O.K.) \\
\hline 7. & If (FM4 is DH) and (NA4 is DL) and (debris is DM) then (output is INSPECT) \\
\hline 8. & If (FM4 is $\mathrm{DH}$ ) and (NA4 is $\mathrm{DH}$ ) and (debris is $\mathrm{DL}$ ) then (output is INSPECT) \\
\hline 9. & If (FM4 is DH) and (NA4 is DL) and (debris is DH) then (output is SHUTDOWN) \\
\hline 10. & If (FM4 is DH) and (NA4 is DH) and (debris is DM) then (output is INSPECT) \\
\hline 11. & If (FM4 is DL) and (NA4 is DH) and (debris is DH) then (output is SHUTDOWN) \\
\hline 12. & If (FM4 is DL) and (NA4 is DH) and (debris is DM) then (output is INSPECT) \\
\hline
\end{tabular}

Figures 8 through 12 are representative plots for 5 of the 20 experiments. Each figure is comprised of 2 plots. The plot on the top is a plot of the 3 features measured during each experiment. FM4 and NA4 Reset correspond to the left Y-axis, the accumulated mass measured by the oil debris sensor corresponds to the right $\mathrm{Y}$-axis. These features are input into a simple fuzzy logic model. The plot on the bottom is the fuzzy logic output. The triangles on the $\mathrm{X}$-axis correspond to when video inspection was performed. The background colors in different shades of gray indicate the O.K., inspect, and shutdown due to damage states.

A short description of Figures 8 through 12 will follow. The results of experiment 2 are plotted on Figure 8. Destructive pitting was first observed on one tooth of the driven gear at reading 2199 and the output plot indicates to inspect the gears. As the damage increases, the inspect changes to shutdown for this experiment. Figure 9 presents the results of experiment 3 . Destructive pitting was first observed on two teeth of both the driven and driver gear at reading 2669 and the output plot indicates to inspect the gears. As the damage increases, the inspect changes to shutdown for this experiment. Experiment 12 is plotted on Figure 10. No damage occurred during this experiment, and the output plot remains in the green region. Experiment 8 is plotted on Figure 11. Initial pitting was first observed on 2 driver teeth and 3 driven teeth at reading 5181 and the output plot indicates to inspect the gears. As the damage increases, the inspect changes to shutdown for this experiment. Experiment 18, not used to define the membership functions, is plotted on Figure 12. At test completion, destructive pits were observed on 6 of the driver teeth and 4 of the driven teeth.

After review of the data from these experiments, the advantage of integrating the features of different measurement technologies into a simple fuzzy logic model is evident. The output gives clear information to the end user when making a decision based on the data. The model developed incorporates the expert knowledge of the diagnostician into a system that can be used to make clear decisions on the status of the geared system.

Several observations are worth noting after careful analysis of the data. The first is that the oil debris feature was more reliable than the vibration features for detecting pitting fatigue failure of spur gears. The vibration features were more sensitive to the environment (operational effects, location, sampling rates, etc.) and these sensitivities were more difficult to quantify or correct for in the field.

Another observation is that a technique for setting accurate threshold limits for vibration algorithms was not clearly defined in the literature [10], [11], [13], [21], [22], [23]. It appears to be a trial and error method that changes for each experiment and each test rig. This makes it very difficult to quantify the false alarms and missed hits using the individual algorithms. If the threshold limits for the vibration algorithms are set at any number above the nominal value of 3.0 , the false alarms would dominate [10], [12], [13], [21].

In comparison, the thresholds for this analysis were determined based on membership functions defined for 17 experiments with varied operational conditions. The process used to define membership functions for the vibration algorithms was an attempt to intelligently define threshold limits. Setting thresholds using membership functions gives the end user more flexibility in defining threshold limits based on levels of damage. However, this method also has its limitations in that it requires several sets of damage data to refine the limits. 

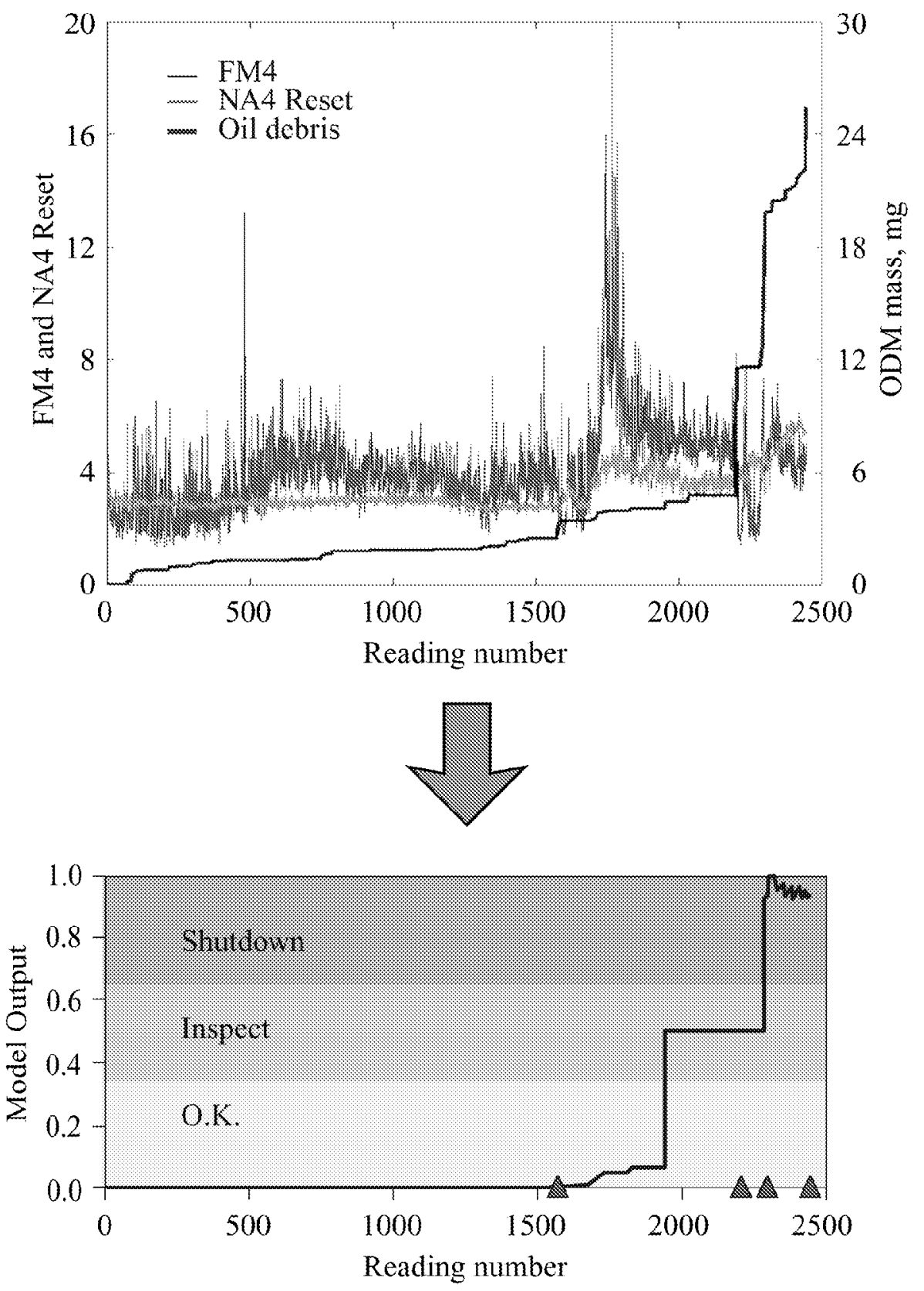

Figure 8: Experiment 2 Features and Model Output 

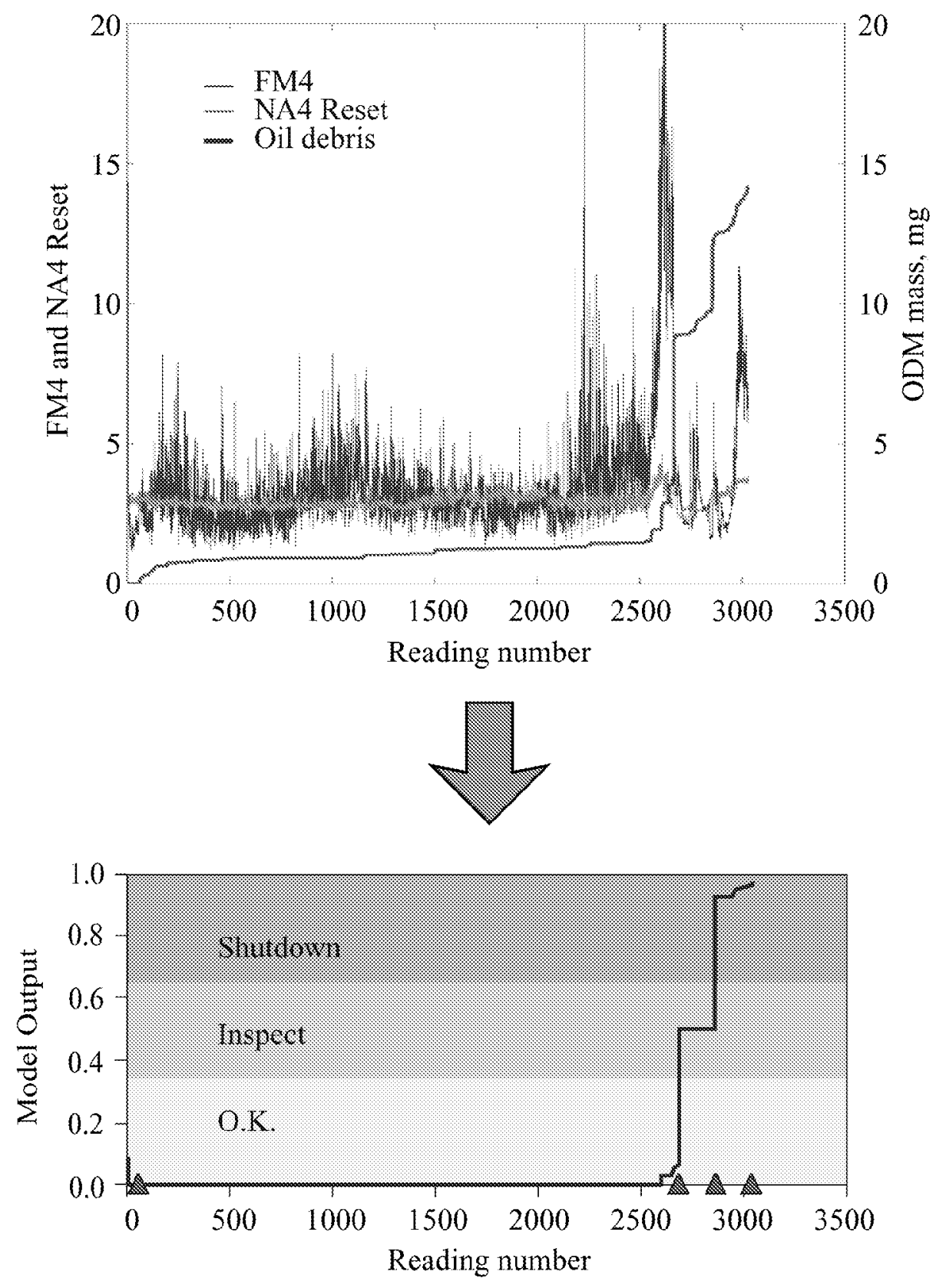

Figure 9: Experiment 3 Features and Model Output 

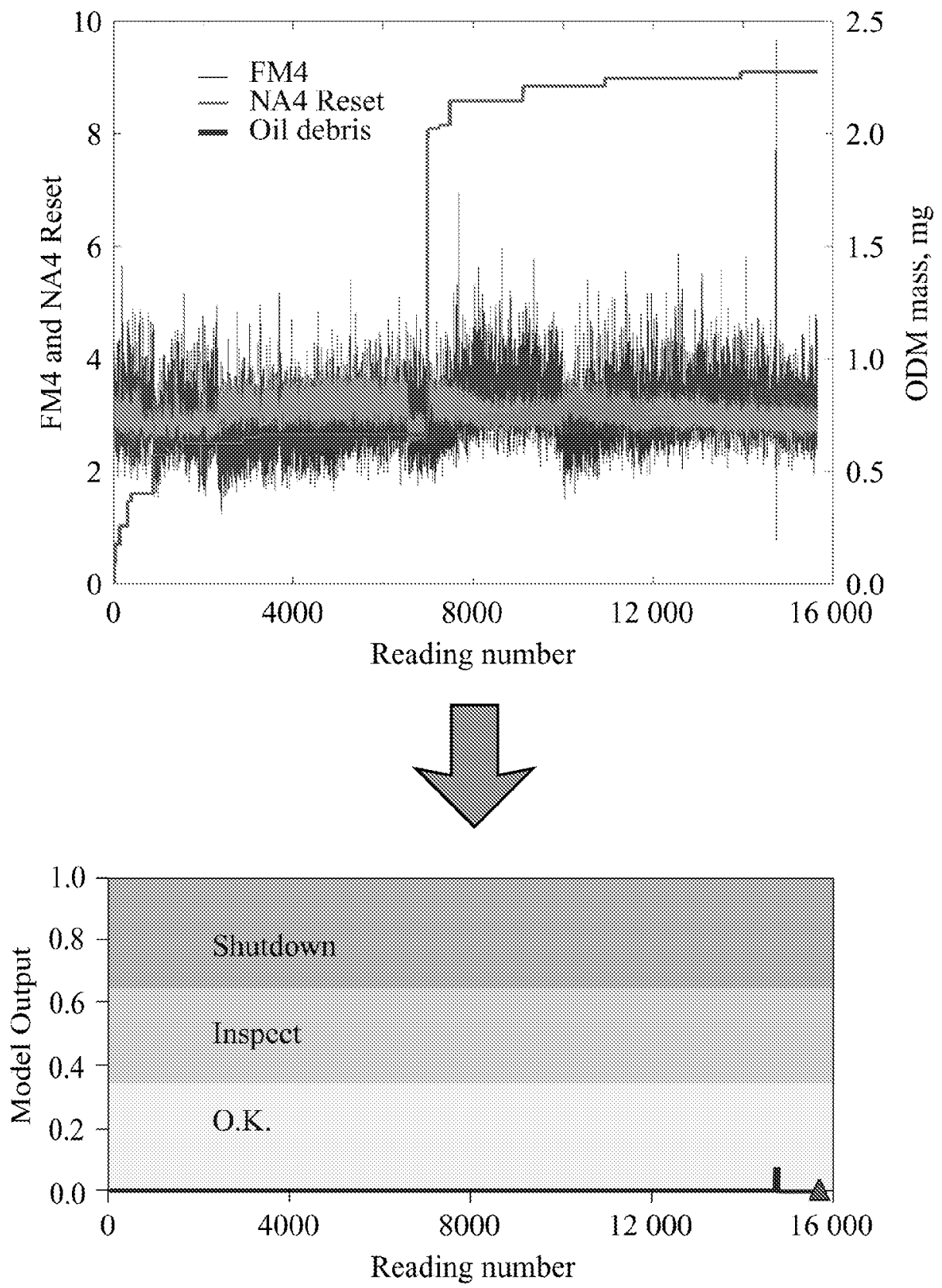

Figure 10: Experiment 12 Features and Model Output 

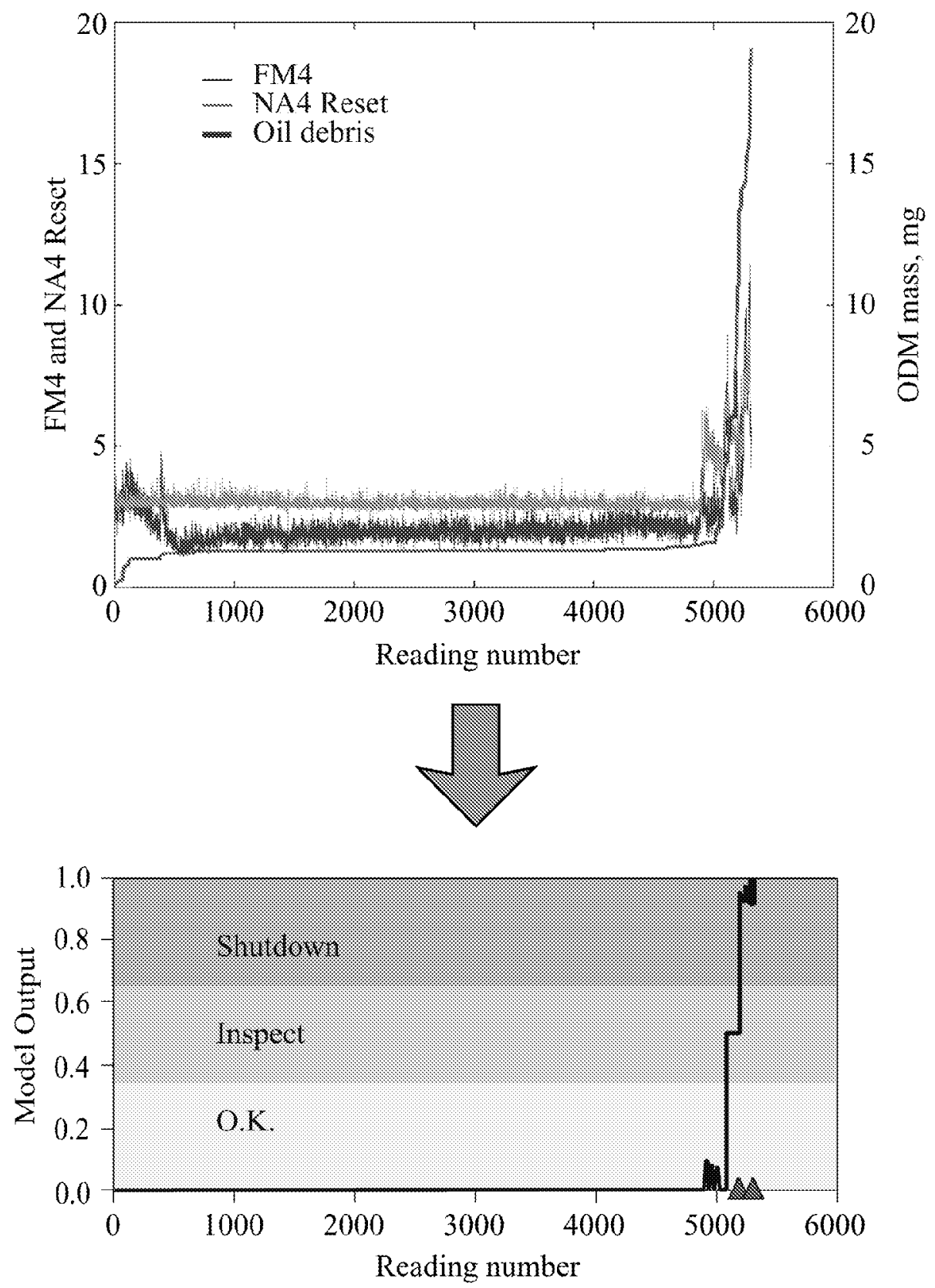

Figure 11: Experiment 8 Features and Model Output 

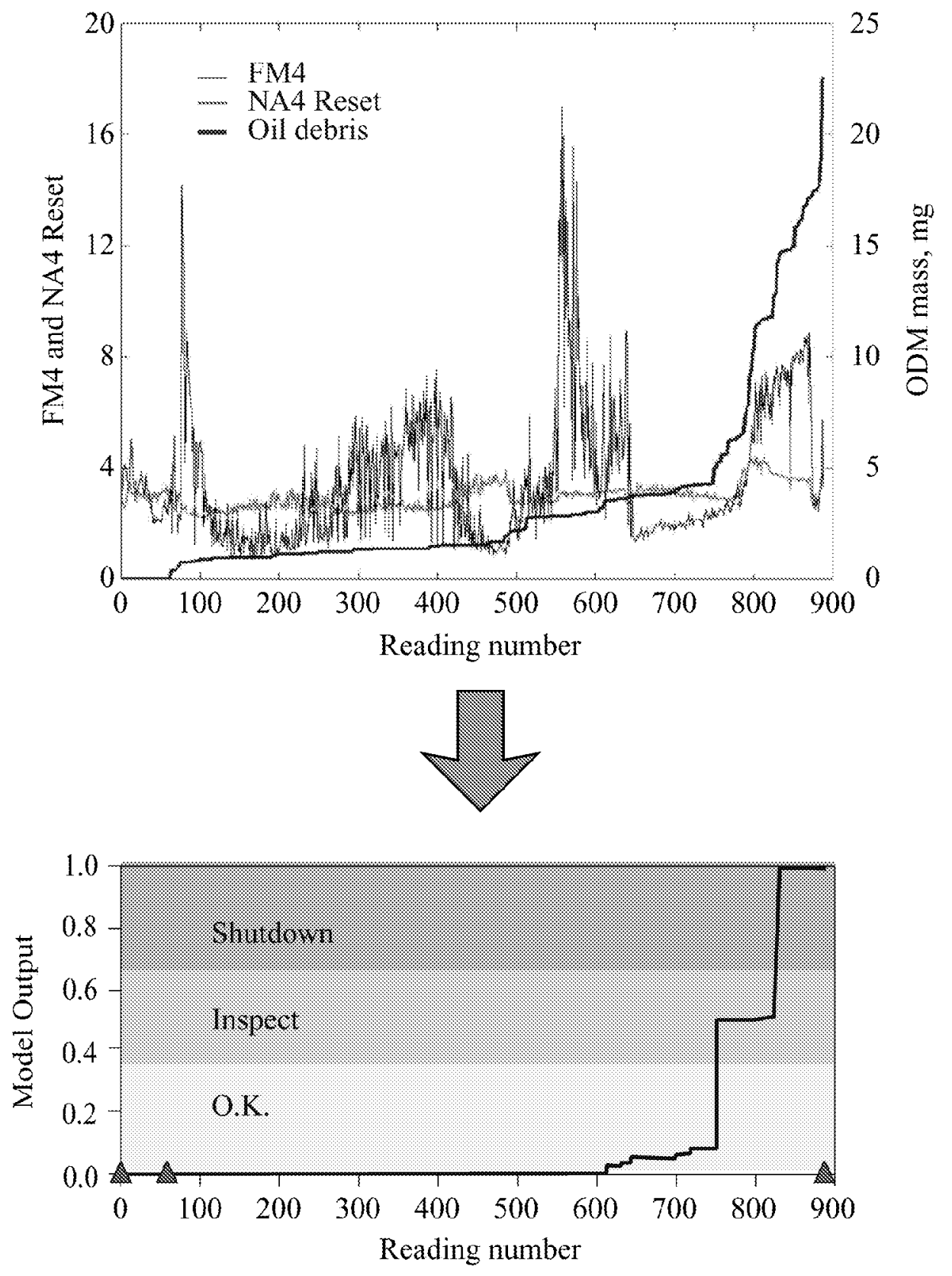

Figure 12: Experiment 18 Features and Model Output 


\section{Conclusions}

The integration of two measurement technologies, oil debris analysis and vibration, results in a system with improved damage detection and decision-making capabilities. Vibration and oil debris data were collected from experiments in the NASA Glenn Spur Gear Fatigue Rig. Using fuzzy logic techniques applied to the oil debris and vibration data, a simple system model was developed that discriminates between stages of pitting wear. Results indicate combining the vibration and oil debris measurement technologies improves the detection of pitting damage on spur gears. As a result of this research, the diagnostic tools used for damage detection in the NASA Glenn Spur Gear Fatigue Rigs have been significantly improved.

Several other findings were made that will impact the development of health monitoring tools for geared systems. The first being, oil debris analysis is more reliable than vibration analysis for detecting pitting fatigue failure of spur gears. The second finding is that some vibration algorithms are as sensitive to operational effects as they are to damage. The third finding is that vibration algorithms FM4 and NA4 Reset do not indicate damage progression, but the increase in oil debris mass is related to damage progression. The fourth finding is that clear threshold limits must be established by the developer of the diagnostic tool if it is to be applied to other systems. The development of membership functions for each parameter will improve this process. It also enables the end user to replace these parameters with their own by adjusting the membership functions. The fifth finding relates to the human factors aspect of diagnostic tool development. As a diagnostician, it is important to identify the end user of the diagnostic tool early on in the process so that he or she can use the diagnostic tool to make clear decisions on the health of the geared system.

\section{References}

[1] Larder, Brian D.: Helicopter HUM/FDR: Benefits and Developments. Proceedings of the American Helicopter Society 55th Annual Forum, Montreal, Canada, May 1999.

[2] Stewart, Ronald $M$. and Ephraim, P.: Advanced HUMS and Vehicle Management Systems Implemented Through an IMA Architecture. Proceedings of the American Helicopter Society 53rd Annual Forum, vol. 53/V2, pp. 1257-1266, 1997.
[3] Pouradier, Jean-Marc, and Trouvé, M: An assessment of Eurocopter experience in HUMS development and support. Proceedings of the American Helicopter Society 57 th Annual Forum, Washington, DC, May 2001.

[4] Howard, Paul L. and Reintjes, J.F.: A Straw Man for the Integration of Vibration and Oil Debris Technologies. Helicopter Health and Usage Monitoring Systems Workshop, G.G. Forsyth, ed., Defense Science and Technology Organization General Document 197, no. 1, pp. 131-136, February 1999.

[5] Byington, C.S.; Merdes, T.A.; and Kozlowski, J.D. (1999): Fusion Techniques for Vibration and Oil Debris/Quality in Gearbox Failure Testing. Proceedings of the Condition Monitoring International Conference, M.H. Jones and D.G. Sleeman, eds., Coxmoor Publishing, Oxford, England, pp. 113-128, April 1999.

[6] Lynwander, Peter: Gear Drive Systems: Design and Application. Marcel Dekker, New York, NY, 1983.

[7] Townsend, Dennis P.: Dudley's Gear Handbook. McGraw-Hill, New York, NY, 1991.

[8] Zakrajsek, James J.; Townsend, D.P.; Oswald, F.B.; and Decker, H.J.: Analysis and Modification of a Single-Mesh Gear Fatigue Rig for Use in Diagnostic Studies. NASA TM105416, May 1992.

[9] Howe, B.; and Muir, D.: In-Line Oil Debris Monitor (ODM) for Helicopter Gearbox Condition Assessment. AD-a347 503, Defense Technical Information Center, Ft. Belvoir, VA, 1998.

[10] Zakrajsek, James J.: An Investigation of Gear Mesh Failure Prediction Techniques. NASA TM-102340, November 1989.

[11] Zakrajsek, James J.; Handschuh, R.F.; and Decker, H.J.: Application of Fault Detection Techniques to Spiral Bevel Gear Fatigue Data. NASA TM-106467, January 1994.

[12] Stewart, R.M.: Some Useful Data Analysis Techniques for Gearbox Diagnostics. Report MHM/R/10/77, Machine Health Monitoring Group, Institute of Sound and Vibration Research, University of Southhampton, July 1977.

[13] Zakrajsek, J.J.; Townsend, D.P.; and Decker, H.J.: An Analysis of Gear Fault Detection Methods as Applied to Pitting Fatigue Failure Data. NASA TM-105950, January 1993. 
[14] Dempsey, P.J. and Zakrajsek, J.J.: Minimizing Load Effects on NA4 Gear Vibration Diagnostic Parameter. NASA TM210671, February 2001.

[15] Dempsey, P.J.: Gear Damage Detection Using Oil Debris Analysis. NASA TM-210936, September 2001.

[16] Zadeh, Lotfi Asker: Fuzzy Logic Advanced Concepts and Structures. IEEE Educational Activities Board. IEEE, Piscataway, NJ, 1992.

[17] Mamdani, E.H.; and Assilan, S.: An Experiment in Linguistic Synthesis With a Fuzzy Logic Controller. International Journal of Man-Machine Studies, Vol. 7, No. 1, 1975, pp. 1-13.

[18] Zadeh, L.A.: Outline of a new approach to the analysis of complex systems and decision processes. IEEE Transactions on Systems, Man, and Cybernetics, Vol. 3, No. 1, pp. 28-44, Jan. 1973.
[19] Jantzen, Jan: Tutorial on Fuzzy Logic. Technical University of Denmark, Department of Automation, Tech. Report No. 98-E 868 (logic), April 16, 1999.

[20] Fuzzy Logic Toolbox for Use With MATLAB ${ }^{\circledR}$ : MathWorks, Inc., Natick, MA, January 1998.

[21] Zakrajsek, James J.: A Review of Transmission Diagnostics Research at NASA Lewis Research Center, NASA TM-106746, 1994.

[22] Zakrajsek, James J.; Decker, H.J.; Handschuh, R.F.; and Lewicki, D.G.: Detecting Gear Tooth Fracture in a High Contact Ratio Face Gear Mesh. NASA TM106822, January 1995.

[23] Zakrajsek, J.J.; Townsend, D.P.; Lewicki, D.G.; Decker, H.J., and Handschuh, R.F.: Transmission Diagnostic Research at NASA Lewis Research Center, NASA TM-106901, May 1995. 


\section{REPORT DOCUMENTATION PAGE}

Public reporting burden for this collection of information is estimated to average 1 hour per response, including the time for reviewing instructions, searching existing data sources, gathering and maintaining the data needed, and completing and reviewing the collection of information. Send comments regarding this burden estimate or any other aspect of this collection of information, including suggestions for reducing this burden, to Washington Headquarters Services, Directorate for Information Operations and Reports, 1215 Jefferson Davis Highway, Suite 1204, Arlington, VA 22202-4302, and to the Office of Management and Budget, Paperwork Reduction Project (0704-0188), Washington, DC 20503.

\begin{tabular}{|l|c|c|}
\hline 1. AGENCY USE ONLY (Leave blank) & $\begin{array}{c}\text { 2. REPORT DATE } \\
\text { July } 2002\end{array}$ & $\begin{array}{c}\text { 3. REPORT TYPE AND DATES COVERED } \\
\text { Technical Memorandum }\end{array}$ \\
\hline
\end{tabular}

4. TITLE AND SUBTITI

Integrating Oil Debris and Vibration Gear Damage Detection Technologies Using Fuzzy Logic

6. AUTHOR(S)

5. FUNDING NUMBERS

Paula J. Dempsey and Abdollah A. Afjeh

7. PERFORMING ORGANIZATION NAME(S) AND ADDRESS(ES)

National Aeronautics and Space Administration

John H. Glenn Research Center at Lewis Field

Cleveland, Ohio 44135-3191

WU-728-30-10-00

9. SPONSORING/MONITORING AGENCY NAME(S) AND ADDRESS(ES)

10. SPONSORING/MONITORING
AGENCY REPORT NUMBER

National Aeronautics and Space Administration

Washington, DC 20546-0001

NASA TM-2002-211126

\section{SUPPLEMENTARY NOTES}

Prepared for the International 58th Annual Forum and Technology Display sponsored by the American Helicopter Society, Montreal, Quebec, Canada, June 11-13, 2002. Paula J. Dempsey, NASA Glenn Research Center; Abdollah A. Afjeh, University of Toledo, Toledo, Ohio 43606. Responsible person, Paula J. Dempsey, organization code 5950, 216-433-3398.

12a. DISTRIBUTION/AVAILABILITY STATEMENT 12b. DISTRIBUTION CODE

Unclassified - Unlimited

Subject Category: 01

Distribution: Nonstandard

Available electronically at htp:/gltrs grenasa.gov/GLTRS

This publication is available from the NASA Center for AeroSpace Information, 301-621-0390.

13. ABSTRACT (Maximum 200 words)

A diagnostic tool for detecting damage to spur gears was developed. Two different measurement technologies, wear debris analysis and vibration, were integrated into a health monitoring system for detecting surface fatigue pitting damage on gears. This integrated system showed improved detection and decision-making capabilities as compared to using individual measurement technologies. This diagnostic tool was developed and evaluated experimentally by collecting vibration and oil debris data from fatigue tests performed in the NASA Glenn Spur Gear Fatigue Test Rig. Experimental data were collected during experiments performed in this test rig with and without pitting. Results show combining the two measurement technologies improves the detection of pitting damage on spur gears.

\section{SUBJECT TERMS}

15. NUMBER OF PAGES

Gears; Transmissions; Oil debris sensor; Damage assessment; Damage detection; Health monitoring; Pitting fatigue

\begin{tabular}{|c|c|c|}
\hline $\begin{array}{c}\text { 17. SECURITY CLASSIFICATION } \\
\text { OF REPORT } \\
\text { Unclassified }\end{array}$ & $\begin{array}{c}\text { 18. SECURITY CLASSIFICATION } \\
\text { OF THIS PAGE } \\
\text { Unclassified }\end{array}$ & $\begin{array}{c}\text { 19. SECURITY CLASSIFICATION } \\
\text { OF ABSTRACT } \\
\text { Unclassified }\end{array}$ \\
\hline
\end{tabular}

NSN 7540-01-280-5500 